\title{
School Choice, School Markets and Children's Urban Socialization
}

\section{Rivière, Clément}

Springer

2017

Rivière , C \& Kosunen , S 2017 , School Choice, School Markets and Children's Urban Socialization . in W T Pink \& G W Noblit (eds), Second International Handbook of Urban

Education . vol. Volume 2, Springer International Handbooks of Education, Springer , Cham , pp. 1291-1305 . https://doi.org/10.1007/978-3-319-40317-5_66

http://hdl.handle.net/10138/311861

https://doi.org/10.1007/978-3-319-40317-5_66

unspecified

acceptedVersion

Downloaded from Helda, University of Helsinki institutional repository.

This is an electronic reprint of the original article.

This reprint may differ from the original in pagination and typographic detail.

Please cite the original version. 


\section{School Choice, School Markets and Children's Urban Socialization}

\section{Clément Rivière and Sonja Kosunen}

\section{Introduction}

Schools in cities are places for children's socialization. This chapter aims to extend and enrich the understanding of urban education by highlighting the relation between children's schooling experiences and their urban socialization, defined as the social process that shapes their representations and action in urban space. The interaction between the school and children's urban "careers" (Becker 1963) has indeed rarely been studied, despite of their porosity: the journey to school, for instance, is generally the first experience of children's autonomous mobility across European countries (Vercesi 2008). More broadly, the urban socialization is often an overlooked dimension in the study of "primary socialization", as defined by Peter Berger and Thomas Luckmann (1966). The purpose of this chapter is to shed light on the urban outcomes of the schooling experiences, such as the acquisition of mobility skills and other socializing effects, and have a closer look at the phenomenon in terms of social class. We specifically concentrate on the journey to school and the transition to lower secondary education, as that shift within the comprehensive education seems somehow to change the child's relationship with the surrounding neighbourhood and public transportation.

Recent studies concerning lower-class pupils (Méndez 2013) and students (Pasquali 2014) entering elite institutions located in well-off areas offer several avenues for research. First, the journeys to school give children information about their own social identity and the identity of other groups, through a better consciousness of the social structure of the city. Second, social ties and networks develop (or do not develop) around these practices of mobility. Third, the child's self-esteem arises in relation to the ability to travel alone across the city. All these processes take place in relation to children's social backgrounds. Therefore, sociological research has highlighted the social differentiation of socialization processes, a result that invites to tackle inequalities and their production among children.

This chapter draws on in-depth interviews conducted with parents living in two socially mixed areas of Paris (France) and Milan (Italy), which allows to investigate the role played by political and socio-cultural contexts in shaping children's urban socialization. In particular, the role of school choice policies, which influence the journeys the children make to school and that have "important implications for children's development of local social capital" (Weller and Bruegel 2009), will be discussed. 
After a short presentation of the methodology and the local contexts of this study, in the first empirical section of this article, we describe the school journeys and related experiences and the embedded processes of urban socialization. Second, we discuss the role of the families' school choices, and schools as producers of urban inequalities among children. The final section focuses on results concerning the school markets as structural contexts for urban socialization processes.

\section{Methodology}

The empirical material used in this chapter was gathered for a study focusing on parental supervision of children's mobility and outdoor play practices (Rivière 2014). Between March 2009 and April 2012, 78 indepth interviews were conducted with 88 parents (51 mothers, 17 fathers and 10 couples) in the cities of Paris and Milan. Forty-three interviews were conducted in Italian in Milan, and 35 in French in Paris, all of them transcribed in the original language and later on subjected to qualitative content analysis. The choice of conducting interviews with parents of at least one child aged from 8 to 14 ( 123 children, 171 overall - see Table 66.1) was based on the interest on studying more accurately the changes in parental supervi- sion in relation to the children's entry to lower-secondary school.

The interest for studying this transition follows the tradition of previous urban studies in urban education (e.g. Weller and Bruegel 2009), which have highlighted the fact that this transition is a shift concerning children's mobility practices. In addition, the usual age for accessing lower-secondary school is the same in France and in Italy (11 years of age - see Table 66.2), and thereby the idea was to define a symmetrical setting: from 3 years before entering lower-secondary school ( 8 years old) to 3 years after (14 years old).

Table 1. Age of interviewees' children

\begin{tabular}{|c|c|c|c|}
\hline Age & Milan & Paris & Total \\
\hline 18 and more & 3 & 5 & 8 \\
\hline $15-17$ & 7 & 4 & 11 \\
\hline 14 & 7 & 6 & $13(10.6 \%)$ \\
\hline 13 & 4 & 7 & $11(8.9 \%)$ \\
\hline 12 & 12 & 9 & 21 (17.1\%) \\
\hline 11 & 8 & 7 & $15(12.2 \%)$ \\
\hline 10 & 6 & 10 & $16(13 \%)$ \\
\hline 9 & 19 & 10 & $29(23.6 \%)$ \\
\hline 8 & 10 & 8 & $18(14.6 \%)$ \\
\hline $5-7$ & 9 & 9 & 18 \\
\hline 4 and less & 3 & 8 & 11 \\
\hline Total & 88 & 83 & 171 \\
\hline Total 8-14 & 66 & 57 & $123(100 \%)$ \\
\hline
\end{tabular}


C. Rivière and S. Kosunen 2017

Table 2. Usual ages at primary and lower-secondary school in France and Italy

\begin{tabular}{l|l|l|l}
\hline School level & Usual age & France & Italy \\
\hline Primary & $6-7$ & Cours préparatoire & Prima elementare \\
\hline- & $7-8$ & Cours élémentaire 1 & $\begin{array}{l}\text { Seconda } \\
\text { elementare }\end{array}$ \\
\hline- & $\mathbf{7 - 9}$ & Cours élémentaire 2 & Terza elementare \\
\hline- & $\mathbf{9 - 1 0}$ & Cours moyen 1 & Quarta elementare \\
\hline- & $\mathbf{1 0 - 1 1}$ & Cours moyen 2 & Quinta elementare \\
\hline Lower secondary & $\mathbf{1 1 - 1 2}$ & Sixième & Prima media \\
\hline- & $\mathbf{1 2 - 1 3}$ & Cinquième & Seconda media \\
\hline- & $\mathbf{1 3 - 1 4}$ & Quatrième & Terza media \\
\hline- & $14-15$ & Troisième (lower secondary & Scuole superiori (high school) \\
& & School) & \\
\hline
\end{tabular}

The structure of the semi-structured thematic interview was divided into three parts: the first one concerned the life in the neighborhood and the residential trajectory of the interviewee; second, the children's usage of public space (with their parents and without them); and the third the parents' perceptions of urban life and social control over their children in public space. The interviews lasted between 30 and $165 \mathrm{~min}$, with an average length of $73 \mathrm{~min}$. As highlighted in Table 3, interviewees were contacted by various means, such as local associations, but also directly in public spaces and via snowball-samplin

Social class is considered an important factor constituting the educational practices of families and educational trajectories of their children (e.g. Lareau 2003; van Zanten 2009). It is defined here as a combination of the parents education level and position in the labour market. The relative proportion of families from lower social backgrounds is slightly higher in Milan (12 working class parents out of 51) than in Paris (7 out of 37), but middle-class parents constitute the majority in our material in both contexts (62 parents out of 88, about 70 \%) (Table 4).

Table 3. Means used to contact interviewees

\begin{tabular}{l|l|l|l}
\hline & Milan & Paris & Total \\
\hline In public or semi-public spaces & 19 & 8 & $27(34.6 \%)$ \\
\hline Through local associations & 12 & 5 & $17(21.8 \%)$ \\
\hline Through school parents associations & 2 & 12 & $14(17.9 \%)$ \\
\hline Through previous interviewees & 7 & 4 & $11(14.1 \%)$ \\
\hline Through common acquaintances & 2 & 6 & $8(10.3 \%)$ \\
\hline Other & 1 & - & $1(1.3 \%)$ \\
\hline Total & 43 & 35 & $78(100 \%)$ \\
\hline
\end{tabular}

Table 4. Social class of the interviewed parents $(\mathrm{N}=88)$

\begin{tabular}{l|c|c}
\hline Social class & Milan & Paris \\
\hline Upper class & 3 & 4 \\
\hline Middle class & 36 & 26 \\
\hline Working class & 12 & 7 \\
\hline Total & 51 & 37 \\
\hline
\end{tabular}


As similar as possible areas have been selected in order to enforce the comparability of this study. More specifically, these neighbourhoods in the two cities share similar features concerning the social and cultural heterogeneity of their population, their morphology, their (north-eastern) location in the city and their historical trajectories.

The area investigated in Milan (Monza-Padova) counted 76,427 inhabitants in 2008. Around one quarter (23.7\%) of them were immigrants (a share ten times higher than 20 years before), which reflects the long history of internal and later on international migration towards this first farming and then small-industry area. The neigh- bourhood is well connected by road and public transportation to the centre of Milan, and its population has progressively changed in relation to the de-industrialisation process, as highlighted by gentrification trends in some delimited sectors of the area.

The area investigated in Paris (Villette-Belleville, 125,393 inhabitants in 2008) is located in the 19th district of Paris, which is on the territory of the former independent municipalities of La Villette and Belleville. It has several features in common with Monza-Padova, in particular its initially rural and then industrial history. The 19th district is a socially and ethnically mixed area (15.7\% of foreigners in 2008$)$ with a lower quality provision of both public and private secondary education, if compared with more central districts of Paris.

\section{Schooling Experience and Urban Experience}

What could be constantly derived from the interviews was the fact that children's practices of mobility are significantly shaped by their school "career" (Becker 1963). In both cities, the primary school in particular appeared as a springboard towards children's urban autonomy. They travelled more often to secondary schools without adult supervision. Simultaneously studies show that in several Western countries, also in France, access to secondary school is one of the two most danger- ous periods for children in terms of fatal traffic accidents (Granié 2010).

The age of the first autonomous journey to (and/or from) school varies accord-ingly to a set of environmental characteristics. First, the possibility for the child to go to school without adult supervision, but along with other children, has a positive impact on the level of autonomy reached at identical steps of the school path. Those children can be neighbours, schoolmates or sons of parent's friends or acquain- tances living in the neighbourhood. In such a perspective, around home the presence of other children who are attending the same school is a precious resource for autonomy.

When she entered primary school, we could not go and pick up her anymore, so I asked two 
sisters living in our building if they would accept to take my daughter with them every morning. This is the way she began going to school without us. And also at the end of the school day, as they were leaving at the same hour. Then, progressively, she did it by herself, in a natural way so to say.

(Father, Employee in an employment agency, two daughters aged 25 and 12, Paris)

However, what parents take into account in their decision is mostly the levels of complexity and perceived danger associated to the journey. As outlined in previous research, living close by the school tends to encourage parents into letting their child travel the journey to school without adults (Lewis and Torres 2010). Beyond the mere physical distance, journeys perceived as more complex (e.g. including heavily trafficked streets to cross, narrow sidewalks and/or deserted spaces) make parents significantly more reluctant to concede autonomy to their children on their way to school, an increasingly frequent request as they grow up.

He has been asking me recently if he could go to school alone, or come back from school alone. It's not so close from here, around twenty minutes walking. He has a large street to cross... And then there is a crossroad with no traffic light, which is quite dangerous. It is true that I don't feel so relaxed when I imagine him walking alone over there. (...) I know that he has a good friend who goes alone to school, but he has only five minutes to walk, and that is not comparable.

(Mother, Engineer in a public research centre, one son aged 9, Paris)

As discussed in previous research (see e.g. Vercesi 2008; Weller and Bruegel 2009; Lehman-Frisch et al. 2012a), the access to secondary education profoundly shapes the autonomization process of children's mobility practices. The first year of lower-secondary school (sixième in Paris, prima media in Milan - with children around 11 years old) means in most cases the start of autonomous journeys to school, as they are not accompanied anymore. The reasons for this change are multiple, as will be shown in the following analyses. The shift towards autonomous mobility within the city frequently occurs during the first days or weeks following the beginning of school year. Table 66.5 describes this phenomenon for the Parisian case: the share of children accompanied by their parents for the journey to school declines along the years and reaches zero when the children reach the age of 11 , whereas the share of children making the journey alone or with school-mates quickly increases as they get older. 
Table 5. The journey to school (Paris)

\begin{tabular}{|c|c|c|c|c|}
\hline Age & $\begin{array}{l}\text { Children } \\
\text { accompanied by an } \\
\text { adult }\end{array}$ & $\begin{array}{l}\text { By an older membe } \\
\text { nof the brotherhood }\end{array}$ & $\begin{array}{l}\text { rMixed forms } \\
\text { accompaniment }\end{array}$ & $\begin{array}{l}\text { fAlone or with } \\
\text { schoolmates }\end{array}$ \\
\hline 8 & $5(62.5 \%)$ & $2(25 \%)$ & $1(12.5 \%)$ & - \\
\hline 9 & $5(50 \%)$ & - & $4(40 \%)$ & $1(10 \%)$ \\
\hline 10 & $4(40 \%)$ & - & $3(30 \%)$ & $3(30 \%)$ \\
\hline 11 & - & $1(14.3 \%)$ & $1(14.3 \%)$ & $5(71.4 \%)$ \\
\hline 12 & - & - & - & $9(100 \%)$ \\
\hline 13 & - & - & - & $7(100 \%)$ \\
\hline 14 & - & - & - & $6(100 \%)$ \\
\hline
\end{tabular}

As a matter of fact, in Milan, a significant number of primary schools do not let pupils go home alone after school, which sheds another light on the role played by school as an institution in shaping the urban autonomy of children. In this case the school provides limitations.

My son goes and comes back to school with one of us, because the head of the school ask parents to do so. Until the last year of primary school. They say they have to be sure the children enter the school, they have to be given to teachers by parents themselves.

(Mother, Educator, one son aged 8, Milan)

At primary school they don't let children go out alone. Someone they know has to come and pick them up.

(Mother, Civil servant, one son aged 10, Milan)

In both cities, interviewees' discourses allow to analytically distinguish four explicative factors for the significant effect of access to secondary school on children's autonomy during the journey to school. First, lowersecondary school, with its irregular hours, make it more difficult for parents to accompany the child. Second, as for cultural, play and clothing practices (Pasquier 2005; Mardon 2010), also peer group pressure among children increases significantly, and is a strong disincentive in relation to be escorted to school by a parent. Third, the parents who are the most reluctant to let their children go alone observe that most pupils do the journey without adults, which further reassures them ${ }^{1}$. Last but not least, and in relation to the previous arguments, lower-secondary school does not serve adults' social relations as much as primary school does, that is to say that the parents are more involved in the activities of primary schools and thereby know the other parents better. Beyond the mere journey to school, this progressive gain of autonomy reverberates on daily mobility practices and outdoor play in the neighbourhood.

${ }^{1}$ The observed autonomy of other children can also be used by less autonomous children when they negotiate more freedom with their parents. 
You don't walk anymore to school with your child. My daughter from the beginning told us... I mean, I did not really consider to accompany her anyway, but she told us: "I warn you, you will not go with me, not even for part of the journey, nothing, you let me go by myself". (...) During the last year at primary school, I was the one saying: "Now you could go alone to school", but she was not interested, she wanted us to go with us. But as soon as she entered lower-secondary school...

\section{So, she associated lower-secondary school and going there by herself?}

She did, yes. From the beginning. Even before, she talked about this during summer holidays: "You won't walk with me to lower-secondary school, no way". (Mother, Project officer, one daughter aged 11, Paris) At the beginning I was accompanying my elder daughter, and then I saw that most of them go back alone from there. So that I felt more relaxed to let her go alone. (Mother, Housewife, two daughters aged 12 and 5, one son aged 9, Milan)

The last year of primary school was frequently considered as a training year for the practices of urban autonomy for the children, before they enrolled to lowersecondary school. This preparation does not only deal with exploring the new itinerary that the child will have to travel. Indeed, it can imply developing mobility skills such as taking public transportation alone (bus and/or underground) or facing new responsibilities such as holding home keys.

I have to say that during the summer between the end of primary school and the beginning of lower-secondary school, I tried to prepare him, to make him more ready by letting him close the door, sometimes I let him go alone to meet friends, so that he could be more used to these kind of things. So that now when he goes out alone I feel relaxed.

(Mother, Housewife, one son aged 12, Milan)

During the last year of primary school, progressively... While going to school, I was walking behind him in order to make him get used walking alone. (...) I wanted him to be ready for his first year at lower-secondary school.

(Mother, Primary school teacher, one son aged 11 and one daughter aged 5, Milan)

We train him to what he will have to face next year, because he will pass from primary to lowersecondary school and will have to go there alone, with the bus. (...) For instance, we have been trying to send him buy bread or similar easy things in the area.

(Father, Sales representative, one son aged 10, Milan)

Attending lower-secondary level in school strongly shapes the representations of what the children can autonomously do in the city. As observed also for many other domains of children's lives (Chamboredon 1991), their position in the school path has consequences on the way they are perceived by adults. In short, the peer group's social pressure attached to attending the lower secondary school made the children willing to make their school journeys unaccompanied. Simultaneously the stage of schooling and the age of the children were considered by the parents in order to let them make the journey alone or with their friends. The 
changes in the everyday schooling from primary to lower secondary education seemed to shape what was considered desirable and what was embarrassing behaviour in terms of making the way to the school. This role played by the school as an institution in shaping children's urban socialization process gets all the more emphasised in the socially differentiated outcomes of school choices, which will be discussed in the following section.

\section{School Choice and Urban Space: Changing Practices}

School choices, in particular when children do not attend the local school, contribute to shaping the children's urban experience as the choice has several consequences on their practices of mobility, but also on their relationship with their own neighbourhood. Schooling outside the neighbourhood fosters children's independent mobility, by confronting them with new experiences such as a regular use of public transportation. Sometimes the distance between home and school is long, due to the choice of a private school or a specific track, for example. As a consequence the pupils travel to school by bus, tram or subway, as described in the following two examples. Because of their choice of a specific track (courses both in French and German in the first case, intensive music education in the second one), these two children had to go to lower-secondary school quite far from home, and had to use the subway autonomously in order to reach the school.

At the beginning of the first year, he was taking the bus together with a friend of his. Then he decided to take the subway, a journey with two changes but which is shorter in terms of time. Besides, he did not like the way so much, as he had to walk to reach the bus station, and it's very dark in wintertime. So that he begun to take the subway, and along his way he meets his schoolmates. He got used to the subway very quickly.

(Mother, Part-time sales advisor, three sons aged 13, 11 and 7, Paris)

Before she used to go walking to school, as the journey was only five minutes long. Now she has to walk to the metro station, and has to change line. The journey in subway lasts around 15 minutes, she could not do that walking. So during the first days at her new lowersecondary school, she went together with her mother. And we found out that she has two schoolmates living in the neighbourhood, and now they often go together. In most cases they wait for each other and go to the station together.

(Father, University teacher, one daughter aged 12, one son aged 8, Paris)

As highlighted by these two quotes, the children who are used to take the public transportation to go to school often meet other pupils along their way. Conversely, their access to local social networks tends to be significantly less extensive than in the case of children who go to the local school. Indeed, most of their schoolmates live in other neighbourhoods, and they have less possibilities to spend time with local kids. In such a perspective, school choices to other than the local school amplify the porosity between children's 
school experience and urban experience, as their social life is largely shaped by the networks they (and their parents) build at school (Weller and Bruegel 2009). This is a reason why an active decision in choosing the local school can be related to a fear of the child otherwise feeling socially isolated in the neighbourhood.

As her secondary school is not located in the neighbourhood, she has friends living... Not everywhere in Paris but further from here, so that to visit her she has to take the subway. She has to leave the neighbourhood. Social relations take her away from here.

(Mother, Certified public accountant, two daughters aged 13 and 10, one son aged 7, Paris)

What I think is that if you go to a school outside your neighbourhood, and all the more if the school is far away, it is much more difficult to make friends and develop networks of friends. You cannot play with your mates after school for example. [...] I don't want her to live a life in which she feels isolated. I really don't. I think it's important to fully live the neighbourhood experience.

(Mother, Project officer, one daughter aged 11, Paris)

The choice of another school than the local one has thus several urban outcomes for the children, as they get earlier used to an autonomous use of public transportation, and also as their social networks are embedded within their school experience. However, it is well-known that families school choices are shaped by their economic, cultural and social resources (see e.g. van Zanten 2009). This sheds a new light on the fact that middle-class and upper-middle class children, who more frequently go to school outside the neighbourhood in our sample, tend to take public transportation earlier than lower-class children. Especially, parents' efforts to progressively train their children to travel in bus or subway alone appear to be related with a desire to anticipate such constraints produced by schooling experience. School choices thus shape the urban socialization of middle-class children in a direct (when they go to school outside the neighbourhood) but also in an indirect way (as their parents anticipate this possibility in their training practices).

Anyway, within the five next years, he will have to... He is gonna do it [go to school in another neighbourhood]. So, without necessarily sending him alone in the subway, we try to teach him how to read a map, how to change between different lines, all kind of things that appear obvious when you are an adult, but are not so obvious for a child to whom they have not been explained. We try to raise his curiosity for this kind of things.

(Father, Finance manager, two sons aged 10 and 3, Paris)

This year she will be dancing ballet, which I am not really keen on. However, the idea was to allow her to do what she wants, but also, as the journey to go there is quite long... It's not a test, but let say that if it's working there, it's gonna work also to go to lower-secondary school I don't know where.

(Mother, Free-lance journalist, one daughter aged 9, one son aged 3, Paris) 
Conversely, lower-class parents in our data rarely discussed future journeys to school as a reason for anticipating the transmission of mobility skills. School choices tend to contain lower-class children in their neighbourhood, whereas they favour the building of more diffuse social networks in the city for middle-class and upper-middle class children. This combination of a differentiated socialization to public transportation and of a differentiated construction of social networks certainly contributes to reproducing socially contrasted uses and representations of urban space. In particular, children's local social capital, defined as the resources deriving from access to social networks (Bourdieu 1980), mobility skills, ability and interest to navigate different kinds of neighbourhoods, appear to be partly shaped by the school choices families make. Upper-class and middle-class families have the means to conduct more sophisticated choices than their lower-class counterparts. This is related also to the practices of intentionally teaching the children how to behave and take their place in urban space, the instruction of how to use the public transportation being a concrete example of that. In other words, such choices contribute to producing a more or less "dominant" or "dominated" relationship with the city, as these practices potentially have several outcomes on urban autonomy (e.g. being able to navigate an unknown area alone, to ask the way to strangers, to face unforeseen interactions...) and social networks. Such socializing and segregating effects should definitely be considered in terms of "transmission of differential advantages to children" (Lareau 2003), that is to say in terms of social inequalities. However, the comparison of the interviews collected in Paris and Milan highlight that school markets play a role in shaping these social contrasts.

\section{School Markets and Children's Urban Socialization}

Considering school trajectories as "careers" allows to observe the role played by school as an institution in shaping children's ways of discovering the city, as the level reached in schooling appears to be more meaningful for urban socialization than biological age. More specifically, children acquire (or do not acquire) mobility skills along their school experience, build social networks inside and/or outside their neighbourhood, navigate different kind of urban environments according to the location of the schools. This chapter has touched upon the relations across families' school choices in Paris and Milan, the diversified and differently locally organized educational provision and their consequences both on school segregation as well as on the different capacities of children from different social backgrounds to use the public space and transportation efficiently.

The socializing effects of the school experience are thus not only related to the institution itself, its agents and users, but also to its location within urban space. Therefore, it is not enough to state that school is an 
agent in the urban socialization process. As a matter of fact, this agent produces socially contrasted outcomes for children in terms of urban skills acquisition (in particular regarding the autonomous use of public transportation), social mix, building of social networks and proximity/ distance to the neighbourhood. It does not only produces school inequalities but also spatial inequalities, notably in relation with school choices, whose urban outcomes for children have rarely been taken into account by research. Most probably, it also produces social differentiation in the urban experience of parents, whose local social capital largely relies on their children's friendship ties (Weller and Bruegel 2009). Whereas relatively few comparative research has been carried on children's mobility in urban space (see e.g. Lehman-Frisch et al. 2012b), the comparative perspective sheds light on the role played by school markets in shaping in a specific way the social differentiation of urban socialization. It appears in particular necessary to take into account local welfare configurations, i.e. the way families, the State and the market interact. In Paris, an "elitist state" organizes a very tense competition between schools and pupils, producing strong social and spatial hierarchies, which is a threat for local schools in socially mixed areas as it increases the likelihood of school segregation. In Milan, a "delegating state" relies more on families and the church as pillars of children's care, which makes the local schools -both public and private - the easiest way to cope with the organization of daily life. The spatial dimension of parental educational strategies appears to be weaker in Milan, whereas a very competitive and spatially hierarchized school market reinforces social differentiation in children's urban socialization in Paris. 


\section{References}

Berger, P., \& Luckmann, T. (1966). The social construction of reality. New York: Random House.

Bourdieu, P. (1980). Le capital social. Notes provisoire [Social capital. Temporary notes]. Actes de la recherche en sciences sociales, 3, 2-3.

Chamboredon, J-C. (1991). Classes scolaires, classes d'âge, classes sociales. Les fonctions de scansion temporelle du système de formation [School classes, age classes, social classes. The temporal scansion functions of the educational system]. Enquête, 6.

Cousin, B. (2009). La stratification sociale en Italie et les paradoxes de la modernisation conservatrice [Social stratification in Italy and the paradoxes of conservative modernization]. In M. Lazar (Ed.), L'Italie contemporaine de 1945 à nos jours [Contemporary Italy from 1945 to present days] (pp. 303-313). Paris: Fayard.

Delvaux, B., \& van Zanten, A. (2006). Les établissements scolaires et leur espace local d'interdépendance [Schools and their local interdependency space]. Revue française de pédagogie, 156, 5-8.

Ghezzi, S. (2012). Parenthood and the structuring of time among urban households in northern Italy. Ethnologie Française, 42(1), 37-44.

Granié, M.-A. (2010). Socialisation au risque et construction sociale des comportements de l'enfant piéton : éléments de réflexion pour l'éducation routière [Socialization to risk and social construction of walking children behaviour: Reflective fragments for road education]. Enfances, Familles, Générations, 12, 88-110.

Lareau, A. (2003). Unequal childhoods. Class, race, and family life. Berkeley: University of California Press.

Lehman-Frisch, S., Authier, J.-Y., \& Dufaux, F. (2012a). 'Draw me your neighbourhood': A gentrified Paris neighbourhood through its children's eyes. Children's Geographies, 10(1), 17-34.

Lehman-Frisch, S., Authier, J-Y., \& Dufaux, F. (2012b). Les enfants et la mixité sociale dans les quartiers gentrifiés à Paris, Londres et San Francisco [Children and social mix in gentrified neighbourhoods of Paris, London and San Francisco]. Caisse Nationale d'Allocations Familiales, Dossier d'études n 153.

Lewis, P., \& Torres, J. (2010). Les parents et les déplacements entre la maison et l'école primaire : quelle place pour l'enfant dans la ville? [Parents and mobilities between home and school: Which place for the children in the city?]. Enfances, Familles, Générations, 12, 44-65.

Mardon, A. (2010). Construire son identité de fille et de garçon : pratiques et styles vestimentaires au collège [Building girls and boys identities: Clothing styles and practices at secondary schools]. Cahiers du genre, 49, 133-154.

Méndez, A. (2013). El Colegio. La formación de una elite meritocrática en el Nacional Buenos Aires [The college. The building of a meritocratic elite]. Buenos Aires: Sudamericana.

Oberti, M. (2000). Relations et dépendances familiales. Regards croisés sur les étudiants français et italiens [Family relations and dependency: A comparative approach of French and Italian students]. Revue de l'OFCE, 73, 259-276. 
Oberti, M. (2005). Différenciation sociale et scolaire du territoire : inégalités et configurations locales [Social and educational differentiation of the territory: Inequalities and local configurations]. Sociétés contemporaines, 59-60, 13-42.

Oberti, M. (2007). L'école dans la ville [The school in the city]. Paris: Presses de Sciences Po.

Oberti, M. (2009). La protection sociale entre la famille, le marché et l'État-providence [Social welfare between the families, the market and the state]. In M. Lazar (Ed.), L'Italie contemporaine de 1945 à nos jours [Contemporary Italy from 1945 to present days] (pp. 315-326). Paris: Fayard.

Oberti, M., Préteceille, E., \& Rivière, C. (2012). Les effets de l'assouplissement de la carte scolaire dans la banlieue parisienne [The impact of the reform of the school district system in Paris Metropolitan area]. Paris: Sciences Po-OSC.

Pasquali, P. (2014). Passer les frontières sociales. Comment les " filières d'élite " entrouvrent leurs portes [Crossing social frontiers. How "Elite Curricula" half-open their doors]. Paris: Fayard.

Pasquier, D. (2005). Cultures lycéennes. La tyrannie de la majorité [High school students' cultures. The tyranny of majority]. Paris: Autrement.

Peugny, C. (2009). Le déclassement [Social downward mobility]. Paris: Grasset.

Rivière, C. (2014). Ce que tous les parents disent? Approche compréhensive de l'encadrement parental des pratiques urbaines des enfants en contexte de mixité sociale (Paris-Milan) [A comprehensive approach of parental supervision of children's urban practices in socially mixed neighbourhoods], PhD dissertation in Sociology. Sciences Po Paris/Università degli studi di Milano-Bicocca.

Seppänen, P. (2006). Kouluvalintapolitiikka perusopetuksessa - Suomalaiskaupunkien koulumarkkinat kansainvälisessä valossa [School-choice policy in comprehensive schooling - school markets of Finnish cities in the international perspective] (Vol. 26). Turku: Finnish Educational Research Association: Research in Educational Sciences.

van de Velde, C. (2008). Devenir adulte. Sociologie comparée de la jeunesse en Europe [Becoming an adult. A comparative sociology of youth in Europe]. Paris: Presses Universitaires de France. 